\title{
IDENTIFIKASI TEKANAN DARAH BERDASARKAN INDEKS MASA TUBUH KARYAWAN STIKES YARSI MATARAM
}

\author{
Zaenal Arifin $^{1}$ ), Baiq Ruli Fatmawati ${ }^{2}$ ), Zuliardi ${ }^{3}$ ), Kurniati Prihatin ${ }^{4}$ ) \\ ${ }^{1)}$ Program Studi Ners; STIKES Yarsi Mataram \\ ${ }^{2,3,4)}$ Program Studi Keperawatan; STIKES Yarsi Mataram \\ z.arifin70@gmail.com
}

\begin{abstract}
ABSTRAK
Asupan gizi yang melebihi kebutuhan tubuh dapat memicu terjadinya kegemukan atau obesitas. Obesitas merupakan faktor resiko terjadinya penyakit tidak menular utama seperti diabetes melitus, jantung iskemik, kanker dan hipertensi. Obesitas merupakan salah satu faktor risiko hipertensi dan berkaitan dengan tekanan darah sistolik. Salah satu indikator untuk mengkur obesitas adalah dengan mengukur indeks massa tubuh (IMT), indeks masa tubuh (IMT) yaitu perbandingan antara berat badan dengan tinggi badan kuadrat dalam meter. Tujuan penelitian ini untuk mengidentifikasi tekanan darah karyawan STIKES Yarsi Mataram berdasarkan Indeks Masa Tubuh (IMT). Metode penelitian ini adalah merupakan penelitian korelasi observasional dengan pendekatan cross-sectional. Sampel dalam penelitian sebanyak 51 responden dengan pengambilan sampel menggunakan purpossive sampling. Hasil uji statistik dengan Anova untuk mengetahui hubungan indeks masa tubuh (IMT) dengan tekanan darah diperoleh hasil sebagai beriktu IMT dengan tekanan darah sistolik $(\mathrm{p}=0.0005)$ dan IMT dengan tekanan darah diastolik $(\mathrm{p}=0.0005)$. Kesimpulan hasil penelitian menunjukan adanya hubungan antara indeks masa tubuh (IMT) dengn tekanan darah. Saran pengendalian berat badan melalui penurunan IMT merupakan salah satu faktor yang dapat menurunkan resiko peningkatan tekanan darah.
\end{abstract}

Kata kunci : Indeks masa tubuh, tekanan darah

\section{ABSTRACT}

Nutritional intake that exceeds the body's needs can be overweight or obesity. Obesity is a risk factor for the incidence of major non-communicable diseases such as diabetes mellitus, ischemic heart disease, cancer and hypertension. Obesity is a risk factor for hypertension associated with systolic blood pressure. Indicator for measuring obesity is by body mass index (BMI), which is the ratio between body and height squared in meters. The purpose of this study was to identify the blood pressure of STIKES Yarsi Mataram employees based on Body Mass Index (BMI). This research method is the first order of observational observations with a cross-sectional approach. The sample in the study was 51 respondents with purposive sampling. The results of statistical tests with ANOVA to see body mass index (BMI) with blood pressure were obtained as BMI with systolic blood pressure $(p=0.0005)$ and BMI with diastolic blood pressure $(p=$ 0.0005). Conclusions: there is a relationship between body mass index and blood pressure. Suggestions: weight control is one of the factors that can reduce the risk of increasing blood pressure.

Key words: body mass index, blood pressure 


\section{Pendahuluan}

Nutritional status (status gizi), adalah keadaan yang diakibatkan oleh keseimbangan antara asupan zat gizi dari makanan dengan kebutuhan zat gizi yang diperlukan untuk metabolisme tubuh (Harjatmo, Par'i, Wiyono, 2017). Asupan gizi yang melebihi kebutuhan tubuh dapat memicu terjadinya kegemukan atau obesitas. Obesitas merupakan dampak adanya ketidakseimbangan energi dimana energi asupan melebihi keluaran energi dalam jangka waktu tertentu.

Obesitas adalah persentase abnormalitas lemak yang dinyatakan dalam indeks masa tubuh (IMT) yaitu perbandingan antara berat badan dengan tinggi badan kuadrat dalam meter. IMT memiliki korelasi positif dengan total lemak tubuh. IMT merupakan salah satu indikator untuk mengkur obesitas, selain dengan mengukur lingkar perut atau lingkar pinggang (Kemenkes, 2017). Kelebihan berat badan dan obesitas dapat diketahui melalui pengukuran indeks massa tubuh (IMT). Kategori overweight jika memiliki IMT > 25 dan obesitas jika didapatkan IMT > 27 (Kemenkes RI, 2013).

IMT didefinisikan sebagai berat badan seseorang dalam kilogram dibagi dengan kuadrat tinggi badan dalam meter $\left(\mathrm{kg} / \mathrm{m}^{2}\right)$. Berdasarkan pengukuran IMT seseorang disesuaikan dengan standar asia-pasifik, obesitas ditandai dengan indeks masa tubuh (IMT) lebih atau sama dengan $25 \mathrm{~kg} / \mathrm{m}^{2}$, sedangkan obesitas sentral ditunjukkan dengan adanya ukuran lingkar pinggang lebih dari $90 \mathrm{~cm}$ pada laki-laki dan lebih dari $80 \mathrm{~cm}$ pada perempuan (Kanazawa et al, 2005; McNeely, 2001). Prevalensi obesitas cenderung mengalami peningkatan.

Prevalensi kelebihan berat badan pada penduduk usia diatas 18 tahun menurut Riskesdas Tahun 2013 sebesar 11,5\%, obesitas dengan IMT $\geq 25$ sebesar
$28,7 \%$ dan obesitas dengan IMT $\geq 27$ sebanyak 15,4\%. Berdasarkan data Riskesdas tahun 2018 terjadi peningkatan proporsi berat badan lebih, obesitas dan obesitas sentral. Proporsi berat badan lebih (overweight) meningkat $2,1 \%$ menjadi $13,6 \%$, proporsi obesitas meningkat sebesar 7\%, sedangkan proporsi obesitas sentral meningkat sebesar 4,4\% (Riskesdas, 2018).

Berdasarkan hasil pengukuran pada penduduk yang berusia diatas 18 tahun di Propinsi Nusa Tenggara Barat (NTB) didapatkan proporsi obesitas sebesar $15 \%$. Sedangkan proporsi obesitas sentral sebesar berdasarkan hasil pengukuran lingkar perut pada penduduk yang berusia diatas 15 tahun adalah sebesar 31,0\% (Riskesdas, 2018).

Obesitas merupakan salah satu permasalahan yang dapat terjadi pada anak-anak, remaja maupun orang dewasa. Obesitas merupakan faktor resiko terjadinya penyakit tidak menular utama seperti diabetes melitus, jantung iskemik, kanker dan hipertensi (WHO, 2016; Kemenkes, 2017). Obesitas merupakan salah satu faktor risiko hipertensi dan berkaitan dengan tekanan darah sistolik. Prevalensi hipertensi pada obesitas lebih besar, sekitar 20-30\% penderita hipertensi memiliki berat badan lebih (Kemenkes, 2013)

Patogenesis keterkaitan obesitas dengan hipertensi dapat disebabkan aktivasi sistem saraf simpatis, jumlah lemak intra-abdominal dan intravaskuler, retensi natrium yang menyebabkan peningkatan reabsorpsi ginjal dan sistem renin angiotensin (Jiang, Lu, Zong, Ruan, Liu, 2016; Kotsis et al, 2010).

Menurut (WHO, 2013) prevalensi hipertensi secara global sebesar 22\%, dengan perkiraan jumlah penderita hipertensi sebanyak 1,13 miliar. sedangkan untuk wilayah Asia Tenggara prevalensi hipertensi sebesar $25 \%$. 
Berdasarkan data Riskesdas tahun 2018 didapatkan bahwa prevalensi hipertensi hasil pengukuran pada penduduk yang berusia diatas 18 tahun sebesar $34,1 \%$ dan diperkiraan jumlah penderita hipertensi sebanyak 63.309.620 orang dengan jumlah kematian sebanyak 427.218 orang.

Hipertensi merupakan kondisi medis yang meningkatkan resiko terjadinya peyakit jantung, otak, ginjal dan kebutaan. Beberapa faktor resiko yang mempengaruhi terjadinya hipertensi adalah konsumsi garam, penggunaan alkohol yang berlebihan, asupan buah dan sayuran yang rendah, kurangnya aktivitas fisik, serta kelebihan berat badan atau obesitas (WHO, 2016).

Hasil penelitian Ulumuddin dan Yhuwono tahun 2018 menunjukkan adanya hubungan antara indeks massa tubuh pada lansia di Desa Pesucen dengan tekanan darah sistol $(\mathrm{p}=0,029$; $\mathrm{r}=0,154),(\mathrm{p}<\alpha=0,05)$ dan tekanan darah diastol ( $\mathrm{p}=0,009 ; \mathrm{r}=0,183),(\mathrm{p}<$ $\alpha=0,01)$.

\section{Metodologi Penelitian}

Penelitian merupakan penelitian korealsi observasional, dengan menggunakan pendekatan cross-sectional. Populasi pada penelitian ini adalah karyawan STIKES Yarsi Mataram dengan sampel sebanyak 51 responden dengan teknik pengambilan purposive sampling. Pengumpulan data dilakukan melalui pengukuran berat badan, tinggi badan dan tekanan darah. Analisa data untuk mengetahui hubungan indeks masa tubuh dengan tekanan darah dengan Anova.

\section{Hasil Penelitian}

1. Karakteristik

Demografi Responden

Tabel 1 Distribusi Frekuensi

Responden Berdasarkan Jenis
Kelmain, Umur, Pendidikan dan Status kepegawaian

\begin{tabular}{clcc}
\hline \multirow{2}{*}{$\begin{array}{c}\text { Karakteristik } \\
\text { Responden }\end{array}$} & \multicolumn{2}{c}{ Frekuensi } \\
& \multicolumn{1}{c}{ N } & \% \\
\hline 1 & Jenis Kelamin & & \\
& Laki-Laki & 23 & 45.09 \\
& Perempuan & 28 & 54.90 \\
2 & Umur & & \\
& 26-35 tahun & 24 & 47.05 \\
& $36-45$ tahun & 19 & 37.25 \\
& $45-55$ tahun & 8 & 15.68 \\
3 & Pendidikan & 1 & 1.96 \\
& SMP & 8 & 15.68 \\
& SMA & 2 & 3.92 \\
& Diploma & 13 & 25.49 \\
& S1 & 27 & 52.94 \\
& S2 & & \\
4 & Status & 25 & 49.01 \\
& Dosen & 26 & 50.98 \\
\hline & Tenaga Kependidikan & 51 & 100 \\
\hline & Total & &
\end{tabular}

Berdasarkan tabel 1 di atas didapatkan responden yang berjenis kelamin laki-laki sebanyak 23 orang $(45,45.09 \%)$ dan perempuan sebanyak 28 orang $(54.90 \%)$. Umur responden terbanyak adalah antara 26-35 tahun yaitu sebanyak 24 orang (47.05\%) dengan tingkat pendidikan yang paling banyak adalah jenjang pendidikan Strata 2 yaitu sebanyak 27 orang (52.94\%). Sedangkan berdasarkan status kepegawaian responden didapatkan sebagai dosen sebanyak 25 orang $(49.01 \%)$ dan sebagai tenaga kependidikan sebanyak 26 orang $(50.98 \%)$.

\section{Distribusi Responden Berdasarkan Indeks Masa Tubuh (IMT)}

Tabel 2 Distribusi Frekuensi Responden Berdasarkan Indeks Masa Tubuh (IMT)

\begin{tabular}{clcc}
\hline No & \multicolumn{1}{c}{$\begin{array}{c}\text { Indeks Masa } \\
\text { Tubuh (IMT) }\end{array}$} & N & \% \\
\hline 1 & $<18.5$ (kurus) & 2 & 3.92 \\
2 & $18.5-22.9$ (normal) & 19 & 37.25 \\
3 & $\begin{array}{l}23-24.9 \\
\text { (overweight) }\end{array}$ & 13 & 25.49 \\
4 & $>25$ (obesitas) & 17 & 33.33 \\
\hline & $\quad$ Total & 51 & 100 \\
\hline
\end{tabular}

Tabel 2 menunjukkan bahwa paling banyak responden ynag memiliki IMT 18.5-22.9 yaitu sebanyak 19 
orang $(37.25 \%)$, dan responden yang memiliki IMT kurang dari 18.5 (< 18.5) sebanyak 2 orang.

\section{Distribusi Responden Berdasarkan Tekanan Darah}

Tabel 3 Distribusi Frekuensi Responden berdasarkan hasil pengukuran tekanan darah

\begin{tabular}{ccccc}
\hline $\begin{array}{c}\text { Tekanan } \\
\text { Darah }\end{array}$ & Mean & SD & $\begin{array}{c}\text { Min- } \\
\text { Maks }\end{array}$ & 95\% CI \\
\hline Sistolik & 111.9 & 12.13 & $90-140$ & $\begin{array}{c}108.5- \\
115.3\end{array}$ \\
\hline Diastolik & 74.95 & 8.463 & $60-90$ & $\begin{array}{c}72.57- \\
77.33\end{array}$ \\
\hline
\end{tabular}

Berdasarkan hasil analisis pada tabel 3 didapatkan rata-rata tekanan darah sistolik responden adalah 111.91 mmHg (95\%CI: 108-115) tekanan sistolik terendah $90 \mathrm{mmHg}$ dan tertinggi $140 \mathrm{mmHg}$ dengan standar deviasi sebesar 12.130.

Hasil estimasi interval dapat disimpulkan $95 \%$ diyakini bahwa rata-rata tekanan darah sistolik responden di STIKES Yarsi Mataram berkisar antara $108.5 \mathrm{mmHg}$ sampai dengan $115.3 \mathrm{mmHg}$.

Sedangkan rata-rata tekanan darah diastolik responden adalah 74.95 mmHg (95\%CI: 72.57-77.33) tekanan darah diastolik terendah $60 \mathrm{mmHg}$ dan tertinggi $90 \mathrm{mmHg}$ dengan standar deviasi sebesar 8.463. Hasil estimasi interval dapat disimpulkan 95\% diyakini bahwa rata-rata tekanan darah diastolik responden di STIKES Yarsi Mataram berkisar antara 72.57 mmHg sampai dengan $77.33 \mathrm{mmHg}$.

\section{Hubungan Indeks Masa Tubuh (IMT) dengan Tekanan Darah}

Tabel 4 Distribusi Rata-Rata Tekanan Darah Sistolik menurut Indeks Masa Tubuh (IMT)

\begin{tabular}{|l|l|l|l|l|}
\hline Variabel & Mean & SD & $95 \%$ CI & p-value \\
\hline IMT & & & & \\
Kurus & 95.00 & 7.071 & $31.47-158.53$ & 0.0005 \\
Normal & 101.18 & 6.890 & $97.86-104.51$ & \\
Overweight & 113.65 & 3.625 & $111.46-115.84$ & \\
Obesitas & 124.56 & 6.973 & $120.97-128.14$ & \\
\hline
\end{tabular}

Rata-rata tekanan darah sistolik pada mereka yang memiliki IMT (<18.5/kurus) adalah $95.00 \mathrm{mmHg}$ dengan standar deviasi $7.071 \mathrm{mmHg}$. Pada mereka yang memiliki IMT (18.5-22.9/berat badan normal) ratarata tekanan darah sistoliknya adalah $101.18 \mathrm{mmHg}$ dengan standar deviasi $6.890 \mathrm{mmHg}$. Pada mereka yang memiliki IMT (23-24.9/berat badan lebih) rata-rata tekanan darah sistoliknya adalah $113.65 \mathrm{mmHg}$ dengan standar deviasi $3.625 \mathrm{mmHg}$. Pada mereka yang memiliki IMT (>25/obesitas) rata-rata tekanan darah sistoliknya adalah $124.56 \mathrm{mmHg}$ dengan standar deviasi $6.973 \mathrm{mmHg}$. Hasil uji statistik didapat nilai $\mathrm{p}=0.0005$, berarti pada alpha $5 \%$ dapat disimpulkan ada perbedaan tekanan darah diantara kategori indeks masa tubuh.

Tabel 5 Distribusi Rata-Rata Tekanan Darah Sistolik menurut Indeks Masa Tubuh (IMT)

\begin{tabular}{|l|l|l|l|l|}
\hline Variabel & Mean & SD & $95 \%$ CI & p-value \\
\hline IMT & & & & \\
Kurus & 65.00 & 5.000 & $1.47-128.53$ & 0.0005 \\
Normal & 67.24 & 5.329 & $64.67-69.81$ & \\
Overweight & 76.92 & 3.840 & $74.60-79.24$ & \\
Obesitas & 83.23 & 4.309 & $81.02-85.45$ & \\
\hline
\end{tabular}

Rata-rata tekanan darah diastolik pada mereka yang memiliki IMT (<18.5/kurus) adalah $65.00 \mathrm{mmHg}$ dengan standar deviasi $5.000 \mathrm{mmHg}$. Pada mereka yang memiliki IMT (18.5-22.9/berat badan normal) ratarata tekanan darah diastoliknya adalah $67.24 \mathrm{mmHg}$ dengan standar deviasi $5.329 \mathrm{mmHg}$.

Pada mereka yang memiliki IMT (2324.9/berat badan lebih) rata-rata tekanan darah diastoliknya adalah $76.92 \mathrm{mmHg}$ dengan standar deviasi $3.840 \mathrm{mmHg}$. Pada mereka yang memiliki IMT (>25/obesitas) rata-rata tekanan darah diastoliknya adalah $83.23 \mathrm{mmHg}$ dengan standar deviasi $4.309 \mathrm{mmHg}$. 
Hasil uji statistik didapat nilai $\mathrm{p}=0.0005$, berarti pada alpha $5 \%$ dapat disimpulkan ada perbedaan tekanan darah diastolik diantara kategori indeks masa tubuh.

\section{Pembahasan}

\section{a. Indeks Masa Tubuh (IMT)}

Indeks massa tubuh atau Body Mass Index (IMT) merupakan suatu ukuran yang dapat digunakan dalam memperkirakan adipositas. Jaringan adipose merupakan masa tidak aktif sebagai tempat penyimpanan energi yang berperan dalam homeostasis energi dan metabolisme (Rossner, 2014). IMT merupakan perbandingan standar berat badan terhadap tinggi badan yang sering digunakan sebagai indikator kesehatan secara umum.

Hasil penelitian ini menunjukkan bahwa sebagian besar responden memiliki indeks massa tubuh normal $(37.25 \%)$. Penelitian ini sejalan dengan penelitian Pratama, Christanto, \& Bebasari (2015) yang menunjukkan bahwa responden paling banyak memiliki indeks massa tubuh normal $(47,93 \%)$.

\section{b. Tekanan Darah}

Tekanan darah adalah kekuatan yang ditimbukan oleh jantung yang berkontraksi seperti pompa, sehingga darah terus mengalir dalam pembuluh darah. Tekanan sistolik merupakan tekanan puncak yang ditimbulkan pada arteri ketika darah dipompa masuk ke dalam pembuluh sewaktu sistol ventrikel (Sherwood, 2013, AHA, 2020).

Seseorang dikatakan hipertensi jika tekanan darah sistolik lebih dari 140 mmHg (Kemenkes, 2013). Hasil penelitian ini menunjukkan bahwa rata-rata tekanan darah sistolik responden adalah $111.91 \mathrm{mmHg}$. Didukung oleh penelitian Abaa, Polii, \& Wowor (2017), menunjukkan bahwa tekanan darah sistolik pada responden mayoritas normal $(85,4 \%)$. Tekanan diastolik adalah tekanan terendah yang ditimbulkan pada arteri ketika darah mengalir keluar darinya ke pembuluh di hilir sewaktu diastol ventrikel (Sherwood, 2013). Seseorang dikatakan hipertensi jika tekanan darah diastolik lebih dari 90 mmHg (Kemenkes, 2013). Penelitian ini menunjukkan bahwa responden memiliki nila rata-rata tekanan darah diastolik paling banyak $74.95 \mathrm{mmHg}$. Hal ini sejalan dengan penelitian Abaa, Polii, \& Wowor (2017) yang menunjukkan bahwa mayoritas responden memiliki tekanan distolik yang normal $(91,6 \%)$.

\section{c. Hubungan IMT dengan Tekanan Darah}

Peningkatan Indeks Massa Tubuh (IMT) erat kaitannya dengan hipertensi baik pada laki-laki maupun pada perempuan. Status IMT yang berlebih, menjadi salah satu prediktor yang dapat menyebabkan peningkatan tekanan darah sistolik dan diastolik sehingga hal ini akan mengakibatkan terjadinya hipertensi pada seseorang. Studi dari Framingham menunjukkan bahwa kenaikan berat badan $10 \%$ dapat meningkatkan tekanan darah 6 $\mathrm{mmHg}$ dalam populasi yang besar (Fikriana, 2016).

Kenaikan berat badan (BB) sangat berpengaruh pada mekanisme timbulnya kejadian hipertensi pada orang yang obesitas, akan tetapi mekanisme terjadinya hal tersebut belum dipahami secara jelas namun diduga pada orang yang obesitas terjadi peningkatan volume plasma dan curah jantung yang akan meningkatkan tekanan darah. Angka kejadian hipertensi pada pasien yang menderita obesitas menurut Sweedish Obese Study didapatkan sebesar $13,5 \%$ dan angka tersebut terus 
meningkat seiring dengan peningkatan IMT dan Waist Hip Ratio (WHR) (Sihombing, 2010).

Dari hasil penelitian ini, dapat dijelaskan bahwa adanya hubungan antara penambahan IMT dengan peningkatan tekanan darah, yang tidak bergantung pada gender. Sejalan dengan penelitian yang dilakukan oleh Hendrik (2012) menunjukan bahwa kenaikan nilai IMT diikuti dengan kenaikan tekanan darah. Selain itu, penelitian yang dilakukan oleh Sarah (2013), didapatkan nilai korelasi antara indeks massa tubuh dengan tekanan darah diastolik adalah 0,246, hal ini menunjukkan ada hubungan antara indeks massa tubuh dan tekanan darah diastolik. Begitu juga dengan hasil penelitian yang dilakukan oleh Utami (2013), bahwa indeks massa tubuh berhubungan dengan tekanan darah sistolik dan tekanan darah diastolik.

Artinya semakin tinggi nilai IMT seseorang maka peluang untuk terkena hipertensi semakin tinggi. Ketika seseorang mengalami obesitas atau dalam kata lain memiliki berat badan yang berlebih maka orang tersebut akan membutuhkan lebih banyak darah untuk menyuplai oksigen dan makanan ke jaringan tubuhnya, sehingga volume darah yang beredar melalui pembuluh darah meningkat, curah jantung ikut meningkat, dan akhirnya tekanan darah ikut meningkat.

\section{Kesimpulan}

Hasil uji statistik didapat nilai $\mathrm{p}=0.0005$, berarti pada alpha 5\% dapat disimpulkan ada perbedaan tekanan darah sistolik dan tekanan darah diastolic diantara kategori indeks masa tubuh.

\section{Saran}

Bagi peneliti selanjutnya, diharapkan dapat melakukan penelitian lebih lanjut pada variabel lain yang dapat mempengaruhi tekanan darah. 


\section{DAFTAR PUSTAKA}

1. American Heart Association (2020) What is High Blood Pressure? https://www.stroke.org

2. Abaa, Y. P., Polii, H., \& Wowor, P. M. (2017). Gambaran Tekanan Darah, Indeks Massa Tubuh, dan Aktivitas Fisik pada Mahasiswa Kedokteran Umum Angkatan Tahun 2014. Jurnal E-Biomedik (EBm), 5. Retrieved from https://ejournal.unsrat.ac.id/index.ph p/ebiomedik/article/view/18509

3. Arisman (2013). Buku Ajar Ilmu Gizi, Obesitas DM dan Dislipidemia. Konsep Teori dan Penanganan Aplikatif. EGC. Jakarta

4. Dante S. Harbuwono, Laurentius A. Pramono, Em Yunir, Imam Subekti. (2018). Obesity and central obesity in Indonesia: evidence from a national health survey. Med J Indones. 27:114-20

5. Dien, N. G., Mulyadi;, \& Kundre, R. M. (2014). Hubungan Indeks Massa Tubuh (IMT) dengan Tekanan Darah pada Penderita Hipertensi di Poliklinik Hipertensi dan Nefrologi BLU RSUP Prof. DR. R. D. Kandou Manado. Jurnal Keperawatan, $09(2), \quad 7$. https://doi.org/10.1111

6. Fikriana R. (2016). Faktor-faktor yang diduga menjadi prediktor terjadinya peningkatan tekanan darah sistolik pada penderita hipertensi. Mesencephalon Jurnal Kesehatan.

7. Hanata dan Freitag. (2015). Hubungan Antara Lingkar Pinggang dan Indeks Massa Tubuh Dengan Hipertensi Pada Polisi Laki-laki di Purworejo, Jawa Tengah. Volume VI. Nomor 2. Hlm 178- 182. Jurnal Kesehatan; 2011

8. Harjatmo, T.P., Par'i, H.M., Wiyono, S. (2017). Bahan Ajar Gizi: Penilaian Status Gizi. Pusat
Pendidikan Sumber Daya Manusia Kesehatan. BPPSDMK. Kementerian Kesehatan.

9. Hendrik. (2012). Hubungan Indeks Massa Tubuh Dengan Tekanan Darah Pada Mahasiswa Fakultas Kedokteran Universitas Sumatera Utara. Skripsi: Fakultas Kedokteran Universitas Sumatera Utara.

10. Jiang SZ, Lu W, Zong XF, Ruan HY, Liu Y. (2016). Obesity and Hypertension. Exp Ther Med.

11. Kanazawa M, Yoshiike N, Osaka T, Numba $\mathrm{Y}$, Zimmet $\mathrm{P}$, Inoue $\mathrm{S}$. Criteria and classification of obesity in Japan and Asia-Oceania. World Rev Nutr Diet 2005;94:1-12.

12. Kementerian Kesehatan RI. (2013). Profil Kesehatan Indonesia Tahun 2013. Jakarta: Kemenkes RI.

13. Kementerian Kesehatan RI. (2017). Profil Kesehatan Indonesia Tahun 2017. Jakarta: Kemenkes RI.

14. Kemenkes (2017). Panduan Pelaksanaan Gerakan Niusantara Tekan Angka Obesitas (Gentas). Direktorat Pencegahan dan Pengendalian Penyakit Tidak Menular. Direktorat Jenderal Pencegahan dan Pengendalian Penyakit.

15. McNeely MJ, Boyko EJ, Shofer JB, Newell-Morris L, Leonetti DL, Fujimoto WY. Standard Definitions of Overweight And Central Adiposity For Determining Diabetes Risk In Japanese Americans. Am J Clin Nutr 2001;74(1):101-7.

16. Pratama, B. F., Christanto, E., \& Bebasari, E. (2015). Pada Mahasiswa Fakultas Kedokteran Universitas Riau, 2(2), 1-10.

17. Ramadhani AD.(2013). Hubungan kontrol tekanan darah dengan indeks massa tubuh pada pasien Hipertensi.

18. Riset Kesehatan Dasar. (2018). Badan Penelitian dan pengembangan kesehatan 
kementerian RI tahun 2018. http://www.depkes.go.id/resource/d ownload/infoterkini/materi_rakorpo p_18/Hasil\%20Riskesdas\%202018. pdf

19. Rossner, S. (2014). Kelebihan Berat Badan dan Obesitas. In J. Mann, \& A. S. Truswell, Buku Ajar Ilmu Gizi (pp.251-257). Jakarta: Buku Kedokteran EGC.

20. Sarah Aina. (2013). Hubungan Indeks Massa Tubuh dengan Tekanan Darah Anak di Sekolah Dasar Negeri 064979 Medan. (http://jurnal.usu.ac.id/index.php/eju rnalfk/article/viewFile/1292/679/

21. Sherwood, L. (2013). Fisiologi Manusia : Dari Sel ke Sistem. (N. Yesdelita, Ed.) (6th ed.). Jakarta: EGC.

22. Sihombing M. (2010). Hubungan Perilaku Merokok, Konsumsi Makanan/Minuman, dan Aktivitas Fisik dengan Penyakit Hipertensi pada Responden Obes Usia Dewasa di Indonesia. Maj Kedokt Indon.

23. Sumayku Irene Moudy. (2014). Hubungan Indeks Massa Tubuh dan Lingkar Pinggang dengan Tekanan Darah pada Mahasiswa Fakultas Kedokteran Universitas Sam Ratulangi.

(http://ejournal.unsrat.ac.id/index.ph p/eclinic/article/viewFile/5022/45

24. Ulumuddin \& Yhuwono. (2018) Hubungan Indeks Massa Tubuh dengan Tekanan Darah pada Lansia di Desa Pesucen, Banyuwangi. Jurnal kesehatan Masyarakat vol.13 no 1 tahun 2018

25. World Health Organization. (2013). Global brief on hypertension. World Health Organization: Geneva. WHO/DCO/WHD/2013.2, 1-40. Retrieved from www. who.int

26. World Health Organization. (2016). Obesity and Overweight. Retrieved from www.who.int 